\title{
PENENTUAN KOMODITAS UNGGULAN TANAMAN BAHAN MAKANAN LAHAN BUKAN SAWAH MELALUI PENDEKATAN OVOP DI KECAMATAN PUNGGUR KABUPATEN LAMPUNG TENGAH
}

\author{
(Determination of Competitive Food Crop Commodities Through The OVOP Approach in Punggur Sub- \\ District, Central Lampung District)
}

Fauzi Nur Dewangga, Raden Hanung Ismono, Fembriarti Erry Prasmatiwi

Jurusan Agribisnis, Fakultas Pertanian, Universitas Lampung, J1. Prof. Dr. Soemantri Brojonegoro No. 1 Bandar Lampung 35145, Telp. 081279365328, e-mail: fauzi.nurdewangga @ yahoo.com

\begin{abstract}
This study aims at determining the most important criteria in supporting the development of One Village One Product (OVOP) products and identifying the competitive as food crop commodities developed in OVOP. The researh was conducted in Astomulyo Village, Punggur Sub-district, Central Lampung District. The research sites were selected purposively with consideration of the size of nonrice land for food crops is very high. Respondents were determined purposively with expert judgement such as: food crop farmers, Agricultural Extensions, offficials of Horticulture/Agriculture Department, and business people. Data were collected with FGD (Focus Group Discussion) and analyzed using AHP (Analysis Hierarchy Process). The study shows that the most important criteria in supporting OVOP product development is capital aspect with the highest weight value of $44.65 \%$, followed by economic aspect $24.83 \%$, appearance and product quality aspect $13.76 \%$, cultural and product specificity aspect $11.43 \%$, and physical and environmental carrying capacity aspect 5.33\%. Pineapple is the best alternative crop with weighted of 44\%, followed by corn $22 \%$, cassava $16.8 \%$, eggplant $10.7 \%$ and cucumber $6.1 \%$.
\end{abstract}

Key words: decision making, OVOP, superior commodity

\section{PENDAHULUAN}

Tanaman bahan makanan merupakan tanaman yang berperan penting pada sektor pertanian sebagai penyokong pertumbuhan perekonomian nasionaldengan memberikan kontribusi Produk Domestik Bruto (PDB) pada tahun 2014 sebesar Rp 361,02 triliun (Kementerian Pertanian 2014). Tanaman ini diproduksi untuk memenuhi kebutuhan hidup yang menyangkut kualitas pemenuhan gizi. Tanaman bahan makanan terdiri dari berbagai macam komoditi yaitu tanaman pangan dan hortikultura yang meliputi tanaman sayuran dan buah-buahan (Kementerian Pertanian 2014).

Peningkatan daya saing pada pelaksanaan pembangunan pertanian ditengah arus globalisasi yang berlangsung saat ini merupakan tuntutan wajib. Jika pemerintah fokus pada pengembangan lahan sawah saja, maka akan terdapat kendala yang dihadapi seperti perubahan iklim, alih fungsi lahan sawah yang sukar dibendung maupun biaya yang semakin mahal untuk membangun lahan persawahan (Utomo 2012).
Hal ini membuat pembangunan pertanian lahan bukan sawah untuk tanaman bahan makanan dijadikan alternatif yang harus didorong melalui berbagai inovasi teknologi sehingga lahan tersebut termanfaatkan secara optimal (Hidayat dan Mulyani 2002).

Kondisi iklim dan topografi Provinsi Lampung berpotensi untuk pengembangan komoditas lahan pertanian bukan sawah dengan pusat pemanfaatan lahan terbesar di Kabupaten Lampung Tengah dengan sentral terdapat di Kecamatan Punggur terutama di Desa Astomulyo (BPS Provinsi Lampung 2014 dan Bappeda Kabupaten Lampung Tengah 2003).

Desa Astomulyo merupakan salah satu desa yang memiliki tingkat luas pemanfaatan lahan pertanian bukan sawah yang tinggi yaitu sebesar 28,26\% namun sebagian sebesar $(75 \%)$ petani belum bisa mengelola hasil pertanian dengan baik (BP3K Kecamatan Punggur 2015). Kondisi ini mengakibatkan harga berfluktuasi, kualitas rendah, kontinuitas belum tercapai serta kemasan dan promosi yang belum baik. 
Hal lain juga belum adanya keterkaitan fungsional yang harmonis. Keterkaitan antara setiap kegiatan agribisnis yang satu dengan yang lain sehingga respon pasar tidak dapat ditangani dengan cepat.

Bentuk pendekatan sistem agribisnis yang dilakukan oleh pemerintah guna keterkaitan fungsional antar kegiatan agribisnis sehingga respon pasar dapat ditangani dengan cepat yaitu menerapkan kebijakan pendekatan One Vilage One Product (OVOP) (Khoirunnisa, Haryono, Nugraha 2013). OVOP merupakan gagasan dari Prof. Morihiki Hiramatsu yang pada saat itu menjabat sebagai Gubernur Oita, Jepang tepatnya pada tahun 1980 (Kemenkop dan UKM 2013).

Kebijakan penerapan OVOP di Indonesia sendiri dicanangkan dan dikembangkan oleh Kementerian Koperasi dan Usaha Kecil Menengah (UKM) Republik Indonesia pada tanggal 8 Juni 2007 (KemenKop dan UKM 2013). OVOP bertujuan untuk menggali dan mempromosikan produkproduk inovatif dan kreatif lokal berdasarkan potensi sumberdaya yang ada, dapat meningkatkan perluasan distribusi pemasaran produk, dan meningkatkan kualitas produk yang bersifat unik khas daerah bernilai tambah tinggi dengan tetap menjaga kelesatarian lingkungan (Kemenkop dan UKM 2013).

Kelebihan lain dari penerapan OVOP yakni dapat dihindarinya persaingan tidak sehat diantara beberapa daerah bertetangga, karena setiap daerah dapat mengembangkan komoditas unggulan yang saling berbeda dalam mengisi pasar yang sama tanpa harus bersaing secara langsung (Efendi 2017). Berikut kriteria OVOP berdasarkan sumber dari KemenKop dan UKM RI 2013, yaitu:

a) Aspek kultur dan kekhasan produk.

b) Aspek penampilan dan kualitas produk.

c) Aspek nilai ekonomi yang tinggi.

d) Aspek modal.

e) Aspek daya dukung fisik dan lingkungan.

Berdasarkan permasalahan diatas, maka penelitian ini bertujuan untuk menentukan kriteria terpenting dalam mendukung pengembangan produk One Village One Product (OVOP) dan mengetahui komoditas unggulan tanaman bahan makanan lahan pertanian bukan sawah yang akan dikembangkan menjadi One Village One Product (OVOP).

\section{METODE PENELITIAN}

Penelitian dilakukan dengan metode survei di Desa Atomulyo, Kecamatan Punggur, Kabupaten Lampung Tengah. Pemilihan lokasi penelitian ditentukan secara sengaja (purposive), dengan pertimbangan daerah ini memiliki tingkat pemanfaatan lahan bukan sawah yang sangat tinggi dibandingkan desa lain di wilayahnya.

Komoditas utama tanaman bahan makanan lahan bukan sawah yang berkembang yaitu tanaman nanas, ubi kayu, jagung, terung, dan ketimun (BP3K Kecamatan Punggur 2015). Pengumpulan data dilakukan pada bulan Maret -Juni 2016.

Responden penelitian dipilih secara sengaja (purposive) dengan pertimbangan ahli dibidangnya sehingga isi dari kuesioner memiliki obyektivitas yang tinggi. Responden tersebut yaitu petani tanaman bahan makanan yang terdaftar dilembaga kelompok tani setempat, peyuluh BP3K Kecamatan Punggur, pejabat pemerintah Dinas Pertanian Tanaman Pangan Hortikultura Kabupaten Lampung Tengah, dan pelaku usaha.

Jenis data yang digunakan pada penelitian ini adalah data primer dan data sekunder. Data primer diperoleh dari subyektif para ahli dengan melakukan penerapan Focus Group Discussion (FGD). Data sekunder berupa data yang dikumpulkan pada penelitian terdahulu maupun laporan yang diberikan oleh lembaga atau instansi terkait dan studi pustaka.

Data dianalisis secara deskriptif kuantitatif dengan menggunakan metode Analisis Hirarki Proses (AHP). AHP adalah alat analisis untuk mengambil keputusan dengan efektif atas persoalan yang kompleks dengan menyederhanakan dan memperepat proses pengambilan keputusan (Saaty 1983). AHP digunakan untuk menjawab tujuan pada penelitian berdasarkan pertimbangan preferensi subyektif reponden dalam mengambil keputusan. Hasil dari pengukuran penilaian perbandingan berpasangan diolah menggunakan bantuan perangkat lunak Expert Choice.

Berikut Gambar 1 terkait struktur hirarki pada penelitian yang dimulai dari tingkat level 1 fokus masalah pembangunan pertanian, level 2 tujuan pembangunan pertanian, level 3 kriteria OVOP, dan terakhir level 4 alternatif tanaman bahan makanan. 


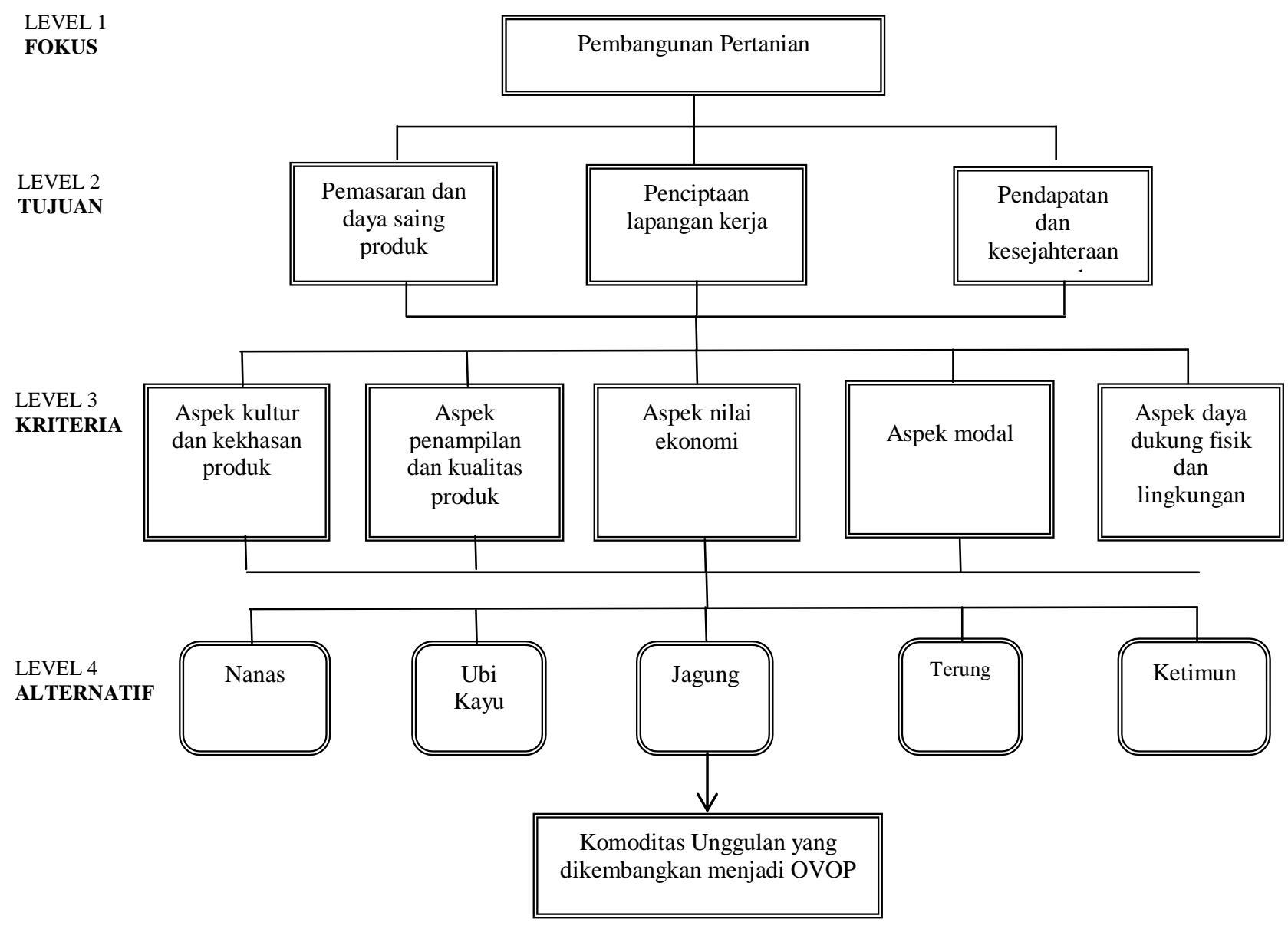

Gambar 1. Struktur hirarki AHP penentuan komoditas unggulan tanaman bahan makanan lahan bukan sawah melalui pendekatan OVOP di Kecamatan Punggur

Berikut proses langkah-langkah AHP dalam menentukan komoditas unggulan lahan bukan sawah melalui pendekatan OVOP :

1) Mendefinisikan masalah dan menentukan solusi.

2) Membuat struktur hirarki dari tingkat level 1 fokus masalah, level 2 tujuan, level 3 kriteria, dan terakhir level 4 alternatif.

3) Membuat matrik perbandingan berpasangan antar tiap tujuan, antar tiap kriteria, dan antar tiap alternatif dengan skala nilai perbandingan berpasangan 1-9.

4) Melakukan perhitungan bobot nilai perbandingan berpasangan yang telah dinormalkankukan perhitungan bobot nilai perbandingan berpasangan yang telah dinormalkan Menghitung nilai vector eigen untuk menemukan bobot nilai priorotas dari setiap matriks perbandingan berpasangan.

5) Menghitung evaluasi total untuk menemukan bobot nilai alternatif pada setiap tujuan maupun kriteria yang telah dihitung.

6) Memeriksa konsistensi hirarki.
7) Memeriksa konsistensi hirarki (jika tidak memenuhi dengan $\mathrm{CR}<0,100$ maka penilaian harus diulang kembali.

\section{HASIL DAN PEMBAHASAN}

\section{Karakteristik Responden}

Hasil penelitian menunjukkan bahwa rata-rata umur responden yaitu 43,2 tahun dengan sebaran kategori umur 30-53 tahun. Sebaran kategori umur tersebut menurut Mantra (2004), mampu mengambil keputusan karena masih termasuk dalam usia produktif. Responden berpendidikan Sekolah Dasar hingga Sarjana sehingga cukup baik untuk menerima inovasi dan menyerap informasi didukung pengalaman usaha yang cukup lama.

\section{Hasil Analisis Kriteria Terpenting Melalui Pendekatan OVOP (One Village One Product) untuk Pencapaian Pembangunan Pertanian}

Persentase perbandingan berpasangan antar tiap kriteria produk OVOP terhadap pencapaian tujuan 
pembangunan pertanian menunjukkan bahwa aspek modal merupakan kriteria terpenting pertama dengan bobot nilai persentase sebesar 44,65\% yang disajikan pada Tabel 1 .

Aspek modal berperan besar dalam membantu prasarana usaha tani di daerah ini. Penyebaran bantuan modal seperti benih atau pupuk pembagiannya belum merata, sedangkan kemampuan petani untuk membiayai usaha taninya sangat terbatas, sehingga mengakibatkan produktivitas yang dicapai belum potensial. hasil (Heriani, Zakaria, dan Soelaiman 2013).

Aspek nilai ekonomi merupakan aspek yang berpengaruh terhadap peningkatan pendapatan masyarakat petani setempat. Aspek nilai ekonomi menempati peringkat terpenting ke dua setelah aspek modal dengan bobot nilai persentase sebesar $24,83 \%$. Hal ini berarti untuk mendukung peningkatan pendapatan petani setempat sangat diperlukannya bantuan modal dari pemerintah terutama bantuan kredit lunak. Karena bantuan seperti ini hanya terfokus pada komoditas yang ditanam di lahan sawah saja.

Aspek penampilan dan kualitas produk menempati peringkat terpenting ke tiga setelah aspek nilai ekonomi. Aspek tersebut merupakan aspek yang berhubungan dengan kemampuan sebuah produk untuk memuaskan kebutuhan konsumen yang mempunyai daya saing tinggi dipasaran karena memiliki (keunikan/ciri fisik, kualitas bagus, harga murah). Aspek penampilan dan kualitas produk memiliki bobot nilai sebesar $13,76 \%$ dikarenakan Lembaga Koperasi Unit Desa (KUD) sebagai lembaga yang menangani proses pasca panen tidak berjalan aktif sehingga petani dalam memasarkan produk pertanian secara pribadi.

Aspek kultur dan kekhasan produk merupakan aspek yang berpengaruh terhadap penyerapan tenaga kerja yang tinggi. Aspek ini memiliki pesentase bobot nilai sebesar $11,43 \%$ dengan peringkat terpenting ke empat. Hal ini karena lebih dalam pelaksanaan usahatani pada era sekarang menekankan pada penggunaan alat mekaniksasi. Penggunaan alat mekanisasi difungsikan untuk mempercepat waktu penyelesaian pekerjaan dalam berusaha tani sekaligus membuat pengeluaran biaya menjadi efisien.

Aspek daya dukung fisik dan lingkungan merupakan aspek yang berpengaruh terhadap kelestarian alam yang diusahakan dalam pelaksanaan usahatani yang tidak menggunakan bahan kimia berlebihan. Aspek daya dukung fisik dan lingkungan menempati posisi tingkat penting terkahir dengan persentase bobot nilai sebesar $5,33 \%$. Hal ini disebabkan penggunaan bahan kimia yang secara tidak berlebihan praktiknya di lapang belum diimplikasikan oleh petani secara menyeluruh di desa ini. Tanaman hortikultura (terung dan ketimun) yang dibudidayakan memerlukan penggunaan bahan kimia secara berlebihan untuk menekan jumlah hama.

\section{Hasil analisis alternatif terpenting tanaman bahan makanan lahan pertanian bukan sawah untuk pencapaian pembangunan pertanian}

Hasil analisis preferensi gabungan responden menunjukkan tanaman nanas menjadi alternatif tanaman terpenting pertama untuk pencapaian tujuan pembangunan pertanian dengan nilai bobot 44\% yang disajikan pada Tabel 2.

Secara berturut-turut setelah aternatif tanaman nanas diikuti oleh alternatif terpenting selanjutnya yaitu alternatif tanaman jagung dengan nilai bobot $22 \%$, ubi kayu dengan nilai bobot $16,8 \%$, terung dengan nilai bobot $10,7 \%$ dan terkahir ketimun dengan nilai bobot $6,1 \%$. Tanaman nanas menjadi alternatif tanaman terpenting pertama dengan pertimbangan tanaman ini lebih unggul dibandingkan beberapa tanaman yang lain. Unggul dalam hal ini dideskripsikan dengan seberapa besar peran penting tiap alternatif tanaman terhadap pencapaian tujuan pembangunan pertanian yang dijelaskan sebagai berikut.

\section{Deskripsi Tiap Alternatif Tanaman Terhadap Tujuan Pemasaran Daya Saing Produk}

\section{a. Tanaman nanas}

Tanaman nanas merupakan alternatif tanaman terpenting pertama dalam meningkatkan pemasaran daya saing produk dengan nilai bobot sebesar $45,4 \%$. Permintaan pasar untuk tanaman ini sangat tinggi yangmembuat saluran distribusi sampai mencakup antar provinsi. Tanaman ini pun telah mendapatkan penghargaan sertifikat produk prima tiga (3), artinya bahwa produk nanas dinyatakan aman dengan level residu dibawah ambang nanas. 
Tabel 1. Persentase bobot nilai tiap kriteria produk OVOP terhadap tiap tujuan pembangunan pertanian

\begin{tabular}{|c|c|c|c|c|}
\hline \multirow[b]{2}{*}{ Kriteria } & \multicolumn{3}{|c|}{ Tujuan Pembangunan Pertanian $(\%)$} & \multirow[b]{2}{*}{$(\%)$} \\
\hline & $\begin{array}{l}\text { Pemasaran dan daya } \\
\text { saing produk }\end{array}$ & $\begin{array}{c}\text { Penciptaan lapangan } \\
\text { pekerjaan }\end{array}$ & $\begin{array}{c}\text { Pendapatan dan kesejahteraan } \\
\text { masyarakat }\end{array}$ & \\
\hline $\begin{array}{l}\text { - Aspek kultur } \\
\text { dan kekhasan } \\
\text { produk }\end{array}$ & 4,90 & 17,00 & 12,40 & 11,43 \\
\hline $\begin{array}{l}\text { - Aspek } \\
\text { penampilan } \\
\text { dan kualitas } \\
\text { produk }\end{array}$ & 26,00 & 8,60 & 6,70 & 13,76 \\
\hline $\begin{array}{l}\text { - Aspek nilai } \\
\text { ekonomi }\end{array}$ & 16,70 & 27,10 & 30,70 & 24,83 \\
\hline - Aspek modal & 45,70 & 42,50 & 45,80 & 44,65 \\
\hline $\begin{array}{ll}\text { - } & \text { Aspek daya } \\
\text { dukung fisik } \\
\text { dan }\end{array}$ & 6,70 & 4,80 & 4,50 & 5,33 \\
\hline
\end{tabular}

Tabel 2. Persentase bobot nilai antar alternatif tanaman terhadap tiap tujuan pembangunan pertanian

\begin{tabular}{lccccc}
\hline \multirow{2}{*}{ Tanaman } & \multicolumn{3}{c}{ Tujuan Pembangunan Pertanian (\%) } & & Vector Eigen \\
\cline { 2 - 4 } & $\begin{array}{c}\text { Pemasaran dan } \\
\text { daya saing produk }\end{array}$ & $\begin{array}{c}\text { Penciptaan } \\
\text { lapangan pekerjaan }\end{array}$ & $\begin{array}{c}\text { Pendapatan dan } \\
\text { kesejahteraan } \\
\text { masyarakat }\end{array}$ & & $(\%)$ \\
\hline - Jagung & 0,202 & 0,188 & 0,270 & 0,245 & 22 \\
- Ubi Kayu & 0,175 & 0,159 & 0,171 & 0,171 & 16,8 \\
- Nanas & 0,453 & 0,441 & 0,426 & 0,434 & 44 \\
- Terung & 0,107 & 0,134 & 0,081 & 0,093 & 10,7 \\
- Ketimun & 0,059 & 0,074 & 0,052 & 0,056 & 6,1 \\
\hline
\end{tabular}

b. Tanaman jagung

Tanaman jagung merupakan alternatif tanaman terpenting ke dua dalam meningkatkan pemasaran daya saing produk dengan nilai bobot sebesar 20,3\%. Penguasaan pasar komoditas ini mencakup lingkup lokal dan antar kabupaten. Komoditas jagung dapat dikonsumsi oleh masyarakat dalam berbagai bentuk olahan, tidak hanya sebagai pangan pokok tetapi juga sebagai makanan selingan, ditambah setengah jadi yang dihasilkan oleh beragam jenis industri hingga sampai pakan ternak. Komoditas ini tidak hanya untuk dikonsumsi sendiri melainkan sepenuhnya diperuntukkan untuk memenuhi kebutuhan domestik, artinya pengembangan komoditas jagung dalam negeri peluangnya masih tinggi.Rentang waktu panen komoditas ini pun tidak terlalu lama berkisar 3-4 bulan.

c. Tanaman ubi kayu

Alternatif tanaman ubi kayu memiliki tingkat terpenting ke tiga dalam meningkatkan pemasaran daya saing produk dengan nilai bobot sebesar $17,6 \%$. Lingkup penguasaan pasar untuk komoditas ini hanya di areal kabupaten, karena wilayah peneltian dekat dengan pabrik olahan ubi kayu. Ubi kayu yang diproduksi merupakan komoditas yang berumur genjah dengan waktu panen kurang dari lebih 12 bulan. Komoditas ini dikhususkan untuk diproduksi menjadi olahan pati tepung tapioka. Tingkat kebutuhan untuk komoditas ini sangat tinggi namun belum dapat diimbangi pasokan bahan baku dari pertanian lokal meski telah didukung oleh inovasi teknologi. Inilah penyebab utama impor masih tinggi. Belum adanya tata niaga yang baik membuat petani enggan melanjutkan perannya dalam rantai nilai ekonomi ubi kayu.

\section{d. Tanaman terung}

Terung merupakan alternatif tanaman terpenting ke empat dengan nilai bobot sebesar 9,30\% dalam meningkatkan pemasaran daya saing produk. Permintaan akan tanaman terung semakin meningkat namun pemasaran komoditas ini masihberada di lingkup lokal dan belum bisa mencukupi kebutuhan domestik. Hal ini disebabkan salah satunya karena penguasaan lahan masih 
bersistem tumpang sari yang memposisikan tanaman ini sebagai produk sampingan.

\section{e. Tanaman ketimun}

Alternatif tanaman ketimun memiliki tingkat terpenting terakhir dengan nilai bobot sebesar $6,0 \%$ dalam meningkatan pemasaran daya saing produk. Pemasaran ketimun mencakup lingkup lokal disamping itu tanaman ini mudah cepat rusak. Tanaman ini diproduksi hanya sebagai tanaman selingan dengan teknik tumpang sari karena penguasaan lahan yang terbatas

\section{Deskripsi Tiap Alternatif Tanaman Terhadap Tujuan Penciptaan Lapangan Kerja}

a. Tanaman nanas

Nanas merupakan alternatif tanaman terpenting pertama dalam meningkatkan penciptaan lapangan kerja dengan nilai bobot sebesar $44,2 \%$. Penguasaan lahan tanaman ini di wilayah penelitian sangat besar yaitu seluas 285 ha. Hal tersebut menjadikan jumlah pasokan produksisangat melimpah, sehingga membutuhkan penyerapan tenaga kerja yang besar. Perawatan tanaman nanas yang mudah dan juga asal bahan baku pun berasal dari turunanmembuat petani nanas masih bertahan melakukan usahatani nanas sampai saat ini.

b. Tanaman Jagung

Alternatif tanaman jagung merupakan alternatif terpenting ke dua dalam meningkatkan penciptaan lapangan kerja dengan nilai bobot sebesar 18,9\%. Luas areal komoditas ini di areal penelitian cukup luas yaitu 34,50 ha. Sumber daya manusia untuk tenaga kerja pun cukup tersedia namun masih kurang dalam inovasi teknologi sehingga mengakibatkan produksi jagung belum bisa memenuhi kebutuhan domestik. Hal ini membuat mayoritas petani pada saat proses awal tanam maupun panen menggunakan tenaga kerja dalam keluarga agar lebih efisien biaya.

c. Tanaman ubi kayu

Alternatif tanaman ubi kayu merupakan tanaman terpenting ke tiga dalam meningkatkan penciptaan lapangan kerja dengan nilai bobot sebesar 16,0\%.
Ketersediaan lahan ubi kayu di tempat penelitian sebesar 32,50 ha. Pertumbuhan luas panen ubi kayu cenderung mengalami penurunan dengan laju penurunan luas lahan ditiap tahunnya. Permasalahan tersebut pun berdampak pada penyerapan tenaga kerja yang terus menurun ditambah harga jual yang terus merosot. Waktu panen juga cukup lama berkisar 12 bulansedangkan kebutuhan petani terus meningkat

d. Tanaman terung

Terung merupakan alternatif tanaman terpenting ke empat dengan nilai bobot sebesar $13,5 \%$ dalam meningkatkan penciptaan lapangan kerja. Penyerapan tenaga kerja untuk tanaman ini tidak terlalu banyak karena tanaman ini diusahakan sebagai selingan bersistem tumpang sari. Tenaga kerja yang digunakan untuk proses tanam dan panen pun menggunakan tenaga kerja dalam keluarga.

e. Tanaman ketimun

Tanaman ketimun merupakan alternatif tanaman terpenting terkahir dalam meningkatkan penciptaan lapangan pekerjaan dengan nilai bobot sebesar 7,5\%. Sama halnya dengan tanaman terung bahwa tanaman ini diusahakan sebagai tanaman selingan dan dalam proses tanam hingga waktu panen tiba juga menggunakan tenaga kerja dalam keluarga. Hanya saja luas panen tanaman ini cenderung turun disetiap tahun dan petani timun pun beralih profesi ke tanaman yang memiliki prospek finansial.

\section{Deskripsi Tiap Alternatif Tanaman Terhadap Tujuan Pendapatan dan Kesejahteraan Masyarakat}

\section{a. Tanaman nanas}

Tanaman nanas merupakan alternatif tanaman terpenting pertamadengan nilai bobot sebesar $42,6 \%$ dalam meningkatkan pendapatan dan kesejahteraan masyarakat petani setempat. Hal ini dikarenakan kualitas produksi yang tinggi dan harga jual yang stabil.Petani nanas dapat menentukan harga jual sehingga membuat petani nanas bertahan untuk berusaha tani nanas dan berusaha untuk meningkatkan produksi dengan memperluas areal lahan. Penguasaan pasar tanaman nanas 
sampai luar daerah hingga membuat tanaman buah ini dapat mengangkat perekonomian setempat. Harga buah nanas saat ini sebesar Rp3.000-3.500 per buah.

\section{b. Tanaman jagung}

Tanaman jagung merupakan tanaman terpenting selanjutnya setelah tanaman nanas berdasarkan peningkatan tujuan pendapatan dan kesejahteraan masyarakat dengan nilai bobot sebesar $27,0 \%$. Harga jual tanaman jagung yang saat ini rendah yaitu sebesar Rp1.800/kg membuat petani jagung enggan untuk semangat berproduksi meskipun permintaan konsumen akan produk tersebut tinggi. Hal tersebut menjadikan sebagian petani jagung beralih ke komoditas lain yang lebih memiliki prospek. Padahal disamping itu limbah jagung dapat digunakan ataupun diolah sebagai pakan ternak yang dapat menjanjikan suatu pendapatan bagi petani

c. Tanaman ubi kayu

Sebagai upaya meningkatkan pendapatan dan kesejahteraan masyarakat, tanaman ubi kayu memiliki peringkat terpenting ke tiga setelah tanaman jagung dengan nilai bobot sebesar $17,1 \%$. Permintaan pasar ubi kayu yang tinggi, pabrik olahan bahan baku yang jarak tempuhnya terjangkau, berikut pemeliharaan dan perawatan ubi kayu yang mudah merupakan kesempatan petani ubi kayu untuk meningkatkan produksi tanaman tersebut.

Waktu panen yang memakan waktu yang panjang yaitu kurang lebih satu tahun dan juga harga jual tanaman ubi kayu yang saat ini rendah yaitu sebesar Rp1.200/kg akhirmya membuat petani ubi kayu enggan untuk semangat meningkatkan produksi (Pradika, Hasyim, Soelaiman 2103). Kualitas produksi yang rendah membuat tanaman ubi kayu belum mampu memenuhi kebutuhan pasar ditengah permintaan pasar yang tinggi.

\section{d. Tanaman terung}

Tanaman terung dengan nilai bobot sebesar $8,1 \%$ merupakan tanaman terpenting ke empat setelah tanaman ubi kayu sebagai upaya meningkatkan pendapatan dan kesejahteraan masyarakat. Tanaman ini memiliki jangka waktu panen pendek yang dapat dipanen tiap hari. Benih yang ditanam petani pun menggunakan benih varietas unggul.

Harga jual tanaman terung yang sering tidak stabil cendurung turun membuat petani enggan untuk semangat berproduksi sehingga dijadikan sebagai tanaman pelengkap saja. Petani terung juga belum bisa membentuk harga karena kurangnya akses informasi mengenai perkembangan harga.Harga terung saat ini sebesar Rp1.000/kg.

e. Tanaman ketimun

Tanaman ketimun dalam meningkatkan pendapatan dan kesejahteraan masyarakat memiliki bobot nilai terendah yaitu sebesar $5,2 \%$. Sama halnya dengan tanaman terung, jangka waktu panen tanaman ini cepat selebihnya tiap hari dapat dipanen. Akan tetapi kualitas produksi masih rendah karena harga jual pun tidak stabil cenderung turun. Harga ketimun saat ini sebebsar Rp700/kg. Biaya pemeliharaan dan perawatan tanaman ini lumayan membutuhkan agak banyak biaya karena tanaman ini rentan terhadap hama dan penyakit.

\section{KESIMPULAN}

Aspek modal merupakan kriteria terpenting dalam mendukung pengembangan produk OVOP . Tanaman nanas merupakan komoditas unggulan pertama yang dikembangkan menjadi produk OVOP.

\section{DAFTAR PUSTAKA}

Balai Penyuluh Pertanian, Perikanan dan Kehutanan (BP3K) Kecamatan Punggur. 2015. Rencana Kerja Tahunan Penyuluh Kabupaten Lampung Tengah. Dinas Pertanian Kabupaten Lampung Tengah. Lampung.

Badan Pusat Statistik. 2014. Lampung Dalam Angka. http://lampung.bps.go.id/publikasi. [20 Desember 2015].

Bappeda Kabupaten Lampung Tengah. 2003. Rencana Tata Ruang Wilayah Kabupaten Lampung Tengah 2004-2014. Dinas Pertanian Kabupaten Lampung Tengah. Lampung.

Efendi. 2017. Pengaruh Program OVOP Terhadap Keuntungan Usahatani Tomat Di Koperasi Mitra Tani Parahyangan Cianjur. IPB Press. Bogor. http://repository.ipb.ac 
.id/handle/123456789/72622. [15 Desember 2015].

Heriani N, Zakaria WA, dan Soelaiman A. 2013. Analisis keuntungan dan risiko usahatani tomat di Kecamatan Sumberejo Kabupaten Tanggamus. JIIA, 1 (2): 169-173. http:// jurnal.fp.unila.ac.id/index.php/JIA/article/vie w/244/243 [ 2Agustus 2016].

Kementerian Pertanian. 2014. Buletin PDB Sektor Pertanian. Pusat Data dan Sistem Informasi Pertanian. Jakarta Selatan. http://pusdatin.setjen.pertanian.go.id/kategori 2-47-buletin-pdb.html. [5 Januari 2015].

Kementerian Koperasi dan UKM. 2013. Rapat Koordinasi Nasional Pengembangan Produk Unggulan Daerah Dengan Pendektan OVOP Melalui Koperasi. Deputi Menteri Bidang Pengkajian Sumberdaya UKMK. Jakarta.

Khoirunnisa A, Haryono D, dan Nugraha A. 2013. Analisis pendapatan dan pengambilan keputusan dalam menentukan tanaman sayuran unggulan di Kecamatan Gisting Kabupaten Tanggamus. JIIA, 1 (2): 98-104. http://jurnal.fp.unila.ac.id/index.php/JIA/artic le/view/235/234. [4 Agustus 2016].
Krueger RA. 1988. Focus Groups: A Practical Guide For Applied Research. Sage Publications. California. http://richard krueger.com. [12 September 2015].

Mantra IB. 2004. Demografi Umum. Yogyakarta. Pustaka Belajar. http://pustakapelajar.co.id /buku/demografi-umum/. [3 juli 2016]

Hidayat A dan A. Mulyani. 2002. Lahan kering untuk pertanian. Jurnal Litbang Pertanian. 27 (2): 1-34. Bogor. http://media.neliti.com. [7 September 2016].

Pradika A, Hasyim AI, dan Soelaiman A. 2013. Analisis pemasaran ubi jalar di Kabupaten Lampung Tengah. JIIA, 1 (1): 25-35. http:// jurnal.fp.unila.ac.id/index.php/JIA/article/view/128/132. [5 Agustus 2016].

Saaty TL. 1983. The Analytical Hierarchy Process. McGraw-Hill. Inc. US. http:// www.scribd.com/mobile/doc/39525925/Anal isis-Hirarki-Proses. [2 Agustus 2015].

Utomo B. 2001. Pembangunan Pertanian Lahan Kering. USU Repository. Medan. http:// repository.usu.ac.id. [2 Juni 2015]. 